\title{
The Biologic Significance of the Aldosterone Concentration in Saliva
}

\author{
ROBERT MCVIE, LENORE S. LEVINE, AND MARIA I. NEW \\ Department of Pediatrics, Division of Pediatric Endocrinology, The New York Hospital, Cornell Medical Center, \\ New York, New York, USA
}

\begin{abstract}
Summary
Salivary aldosterone measurements can be used to study aldosterone secretion and metabolism noninvasively. Salvia and plasma aldosterone concentration were highly correlated during all periods of study; during adrenocorticotrophic hormone (ACTH) administration, a relatively greater amount of aldosterone appeared in saliva; during dexamethasone administration, a relatively smaller amount of aldosterone appeared in saliva.

As plasma cortisol increased with ACTH administration there was an increased relative amount of aldosterone in saliva. DOC (11-deoxycorticosterone) was found in saliva only during ACTH administration. Corticosterone was identified during baseline periods. Salivary aldosterone concentrations were independent of flow.

The data indicate that saliva is an accessible bodily fluid which may be used to monitor the changes in nonprotein bound plasma steroid hormone concentration in children.

\section{Speculation}

Saliva is an accessible bodily fluid which may be used to monitor the changes in nonprotein bound plasma aldosterone concentration and other steroidal hormones.
\end{abstract}

Repeated measurements of free aldosterone levels in children are limited by the inconvenience and difficulty in obtaining complete urine collections, by the large amount of blood necessary, and the discomfort of repeated venipunctures. The aim of this study was to establish that saliva is a biologic fluid which can be used to evaluate the concentration of free aldosterone. This would give a measure of the biologically active fraction of aldosterone and would simplify the investigation of aldosterone metabolism in children.

That salivary hormones may be used to measure nonprotein bound serum hormones was shown by Katz and Shannon $(7,8,9)$ who found that the quantity of cortisol plus cortisone in saliva was equal to the level of dialysable cortisol plus cortisone in plasma. Therefore, these findings predicted that other nonprotein bound steroids would be found in saliva.

Our studies demonstrate that the concentration of salivary aldosterone is a measure of the plasma dialysable aldosterone under conditions of varying dietary sodium during ACTH stimulation and dexamethasone suppression. Therefore, the salivary aldosterone concentration is useful in studies of aldosterone metabolism where changes in aldosterone concentrations must be measured repeatedly and where the biologically active free fraction of aldosterone is of particular interest. Further, collection of saliva is a noninvasive procedure which would permit such studies in infants and children.

\section{MATERIALS AND METHODS}

PATIENT SELECTION

Patients admitted to the Pediatric Clinical Research Center of The New York Hospital-Cornell Medical Center for the evalua- tion of hypertension, or adrenal function, were studied after obtaining informed consent from the patients and their parents. All protocols were approved by this institution's Human Rights in Research Committee. No patients with known or suspected biosynthetic defects of glucocorticoids, mineralocorticoids, or plasma proteins were included in this report. No normal patients received ACTH or dexamethasone in this study.

Twenty-one expectorated saliva samples were obtained from normal children. The ages ranged from 4-16 yr.

\section{SALIVA AND PLASMA COLLECTION}

Parotid saliva was collected by a Lashley cup. The initial model was kindly supplied by Dr. Fred H. Katz. Subsequently, Lashley cups were purchased from $\mathbf{H}$ and I Instrumentation of Teaneck, New Jersey. They were composed of Delrin and stainless steel. Regal Crown Sour Lemon Drops were sucked by the patient until a constant flow of parotid saliva was maintained for $2 \mathrm{~min}$. The following five-min volume was collected and the sample was frozen at $-20^{\circ} \mathrm{C}$ until assayed.

Expectorated saliva was obtained by having the patient expectorate into a plastic cup for 5 min while sucking a sour lemon drop. Expectorated saliva was centrifuged in a refrigerated centrifuge and the supernatant frozen at $-20^{\circ} \mathrm{C}$ until assayed. Electrolytes were not measured in expectorated saliva.

Blood was withdrawn during the saliva collection, heparinized, centrifuged, and plasma separated and stored at $-20^{\circ} \mathrm{C}$ until assayed.

Samples were collected after $2 \mathrm{hr}$ ambulation. The time of collection was between 0730 and 0830 . Patients had been fasting since retiring the night before.

\section{STEROID METHODS}

The method of Abraham and associates $(1,2,6,10,12)$ was used for the radioimmunoassay of the corticosteroids. The assay for corticosteroids was modified as follows for saliva.

To $4 \mathrm{cc}$ of saliva was added 1000 counts per minute of radiolabeled aldosterone, DOC, cortisol, and corticosterone in a volume of $50 \mu \mathrm{l}$ for each steroid. Saliva was extracted with dichloromethane using a volume that was three times the saliva volume.

The plasma renin activity was determined by the method of Sealey et al. (14).

Urinary aldosterone was determined by the method of Charmakjian et al. (2).

\section{PERIODS OF STUDY}

1) Low sodium diet-10 mEq of sodium daily for 3-5 days. 2) Regular sodium diet $-87 \mathrm{mEq}$ of sodium $/ \mathrm{m}^{2}$ daily for 3-5 days. 3) High sodium diet $-150 \mathrm{mEq}$ of sodium $/ \mathrm{m}^{2}$ daily for 3-5 days. ACTH stimulation. 1) One day ACTH test-40 U ACTH (ACTHAR Armour) given by constant iv infusion over $8 \mathrm{hr}$. 2) Fiveday ACTH test-40 U ACTH given over each 24 -hr period.

Dexamethasone suppression. Dexamethasone $0.5 \mathrm{mg}$ was administered orally every $6 \mathrm{hr}$ for 1-10 days.

Assay of sour lemon drops dissolved in sterile water revealed 
Table 1. The interrelationship of aldosterone concentration in plasma, saliva and urine, and plasma renin activity ${ }^{1}$

\begin{tabular}{|c|c|c|c|c|c|c|c|}
\hline & & & & $\begin{array}{l}\text { Plasma aldoste- } \\
\text { rone (ng/dl) }\end{array}$ & $\begin{array}{l}\text { Salivary aldoste- } \\
\text { rone }(\mathrm{ng} / \mathrm{dl})\end{array}$ & $\begin{array}{l}\text { Plasma renin ac- } \\
\text { tivity }(\mathrm{ng} / \mathrm{ml} / \mathrm{hr})\end{array}$ & $\begin{array}{l}\text { Urinary aldoste- } \\
\text { rone }(\mu \mathrm{g} / 24 \mathrm{hr})\end{array}$ \\
\hline Patient & Age (yr) & Sex & Diagnosis & $\mathbf{A}$ & B & $\mathbf{C}$ & D \\
\hline \multirow[t]{13}{*}{ R. W. } & 12 & $\mathbf{M}$ & Polycystic kidney & 6.3 & 2.2 & 5.8 & 3.2 \\
\hline & & & & 31.9 & 6.0 & 6.7 & 19.5 \\
\hline & & & & 37.5 & 6.3 & 6.6 & 31.8 \\
\hline & & & & 4.0 & 1.1 & 1.9 & 0.7 \\
\hline & & & & 8.5 & 1.3 & 2.2 & 6.9 \\
\hline & & & & 12.8 & 4.6 & & 4.9 \\
\hline & & & & 11.0 & 5.0 & & \\
\hline & & & & 18.6 & 7.3 & & 27.0 \\
\hline & & & & 5.6 & 1.8 & 0.3 & 10.8 \\
\hline & & & & 4.4 & 1.8 & 0.63 & 1.3 \\
\hline & & & & 30.0 & 5.5 & 6.3 & 6.7 \\
\hline & & & & 100.0 & 20.0 & & 21.2 \\
\hline & & & & 127.0 & 28.0 & & 45.8 \\
\hline \multirow[t]{7}{*}{ M. D. } & 20 & $\mathbf{M}$ & Klinefelter's syndrome & 10.1 & 4.6 & & \\
\hline & & & & 24.0 & 8.0 & & 6.5 \\
\hline & & & & 71.0 & 21.0 & & 38.0 \\
\hline & & & & 9.7 & 4.0 & & \\
\hline & & & & 13.9 & 5.8 & & 5.8 \\
\hline & & & & 16.9 & 7.1 & & 7.2 \\
\hline & & & & 13.4 & 3.7 & 3.88 & 19.3 \\
\hline \multirow[t]{5}{*}{ R. P. } & 14 & $\mathbf{M}$ & Normal & 12.2 & 3.9 & 4.0 & 37.4 \\
\hline & & & & 18.7 & 3.3 & 2.5 & 12.8 \\
\hline & & & & 59.4 & 12.6 & 5.8 & 15.2 \\
\hline & & & & 62.7 & 14.7 & 10.1 & 32.7 \\
\hline & & & & 73.0 & 34.4 & & \\
\hline L. $\mathbf{K}$. & 4 & $\mathrm{~F}$ & Hypertension & 6.3 & 2.9 & & \\
\hline R. M. & Adult & $\mathbf{M}$ & Normal & 9.5 & 3.1 & & \\
\hline M. N. & Adult & $\mathbf{M}$ & Normal & 10.9 & 2.5 & & \\
\hline \multirow[t]{3}{*}{ K. K. } & Adult & $\mathbf{M}$ & Normal & 10.9 & 3.2 & & \\
\hline & & & & 10.6 & 3.7 & & \\
\hline & & & & 135.0 & 36.8 & 22.0 & \\
\hline \multirow[t]{4}{*}{ D. M. } & 14 & $\mathbf{M}$ & Coarctation of aorta & 13.8 & 2.6 & 8.6 & \\
\hline & & & & 153.0 & 32.4 & 16.0 & \\
\hline & & & & 4.7 & ND & & \\
\hline & & & & 66.8 & 20.7 & & \\
\hline J. M. & Adult & $\mathbf{F}$ & Normal & 63.0 & 22.0 & & \\
\hline N. C. & 7 & $\mathbf{F}$ & Turner's syndrome & 54.0 & 13.5 & & \\
\hline A. $\mathrm{H}$. & 11 & $\mathbf{F}$ & Short stature & 110.0 & 22.0 & 16.0 & 20.6 \\
\hline K. $\mathbf{P}$. & Adult & $\mathbf{F}$ & Turner's syndrome & 30.0 & 6.4 & 15.0 & 24.0 \\
\hline \multirow[t]{3}{*}{ D. R. } & 15 & $\mathbf{F}$ & Turner's mosaicism & 33.6 & 14.4 & & 55.0 \\
\hline & & & & 45.3 & 10.4 & 28.0 & 34.5 \\
\hline & & & & 15.6 & 2.6 & 7.9 & 8.0 \\
\hline \multirow[t]{11}{*}{ A. $R$. } & 18 & $\mathbf{F}$ & Hypertension & 14.9 & 2.7 & 13.0 & 7.6 \\
\hline & & & & 6.0 & 2.5 & 7.5 & 17.4 \\
\hline & & & & 4.6 & 1.4 & 2.4 & 8.1 \\
\hline & & & & 2.6 & 1.0 & 1.2 & 4.0 \\
\hline & & & & 2.6 & 0.8 & $0.45^{\circ}$ & 1.7 \\
\hline & & & & 36.5 & 6.2 & 15.0 & 17.7 \\
\hline & & & & 46.8 & 8.0 & 17.0 & 18.3 \\
\hline & & & & 57.4 & 13.0 & 7.7 & 43.6 \\
\hline & & & & 41.0 & 10.0 & 19.0 & 55.5 \\
\hline & & & & 1.8 & ND & 2.7 & 0.8 \\
\hline & & & & 2.6 & ND & 3.1 & 1.0 \\
\hline
\end{tabular}


Table 1. Continued

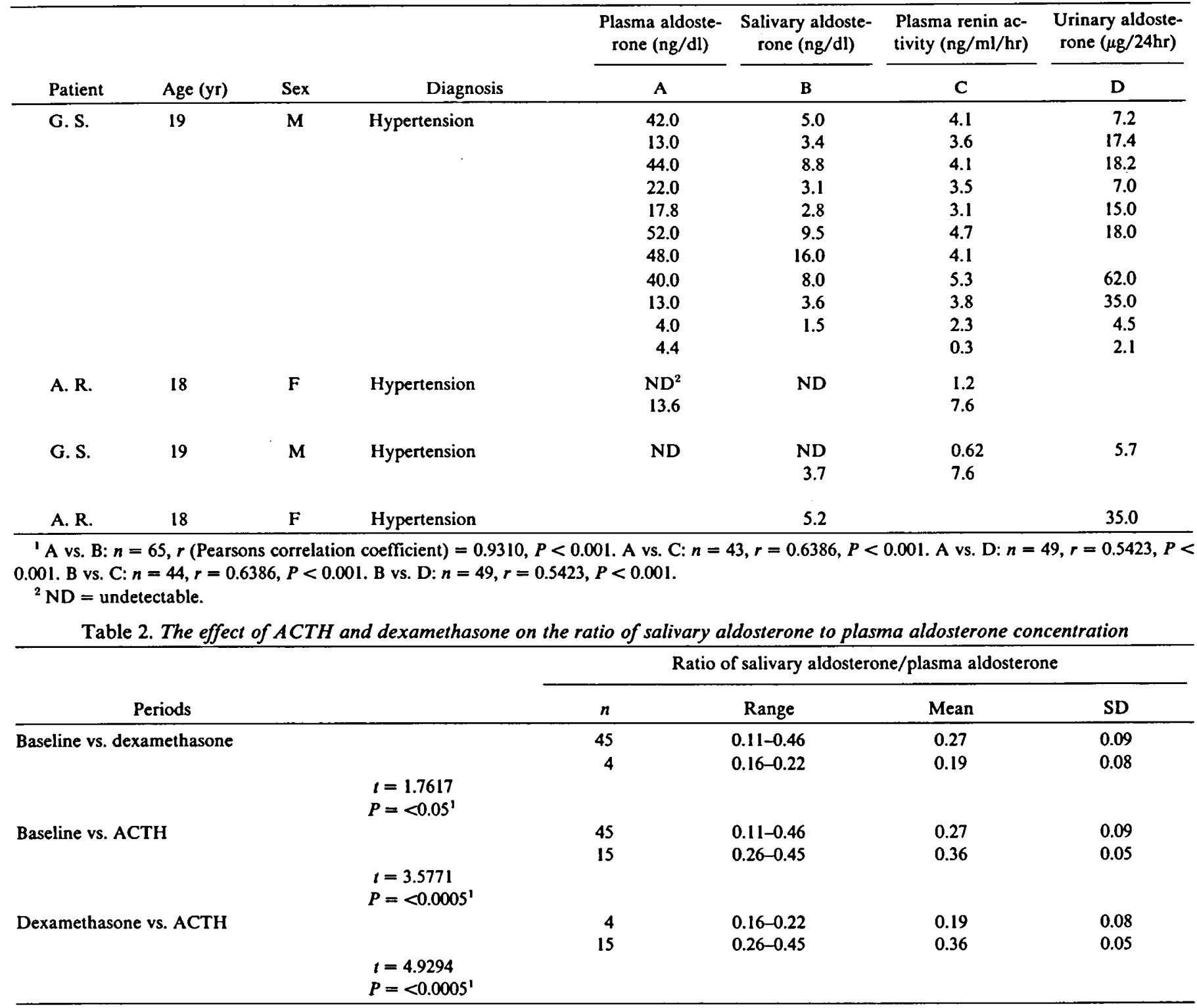

'Single tailed $t$ test.

the sour lemon drop contained no material affecting the radioimmunoassay for steroids. When assayed for electrolytes, each sour lemon drop was found to contain $0.1 \mathrm{mEq}$ of sodium. No potassium was found.

\section{CALCULATIONS}

Standard parameters of the radioimmunoassay were calculated by a program designed to our specifications by the Cornell University Medical Center computer facility personnel. Statistical calculations were performed using a statistical package designed by the Computer Center faculty. Calculations were performed on an IBM $370 / 145$ computer.

\section{RESULTS}

MEASUREMENT OF SALIVARY ALDOSTERONE CONCENTRATION AND ITS RELATIONSHIP TO OTHER PHYSIOLOGIC PARAMETERS

Samples of parotid and expectorated saliva obtained simultaneously gave identical results for aldosterone concentration.

Plasma and salivary aldosterone concentrations, urinary aldosterone excretion and plasma renin activity under all conditions are presented in Table 1. Saliva and plasma aldosterone concentrations were highly correlated to urinary aldosterone excretion and the plasma renin activity.
Plasma and salivary aldosterone concentrations were highly related during periods of changes in dietary sodium (Fig. 1).

In 21 normal children for whom the dietary sodium was unknown, the mean level of salivary aldosterone concentration was $2.5 \mathrm{ng} / \mathrm{dl}$. The range was from $<1-7 \mathrm{ng} / \mathrm{dl}$. This is in agreement with our findings for hospitalized children whose mean salivary aldosterone concentration on a regular sodium diet was $3.1 \mathrm{ng} / \mathrm{dl}$.

During changes in dietary sodium intake, the ratio of salivary to plasma aldosterone concentration was relatively constant for each patient. In contrast, the administration of ACTH and dexamethasone resulted in consistent alterations in the ratio of salivary to plasma aldosterone concentration: higher ratios were noted during the administration of ACTH (average 0.36), lower ratios were noted during the administration of dexamethasone (average 0.19 ) (Table 2).

As the level of plasma cortisol increased during ACTH administration, the ratio of salivary aldosterone to plasma aldosterone also increased (Fig. 2).

\section{OTHER HORMONES MEASURED IN SALIVA}

A small number of assays were done for other hormones. DOC was not found in the saliva of any subject in the unstimulated state. During the administration of ACTH, the level of salivary DOC was approximately $6 \%$ of the simultaneous plasma level. 


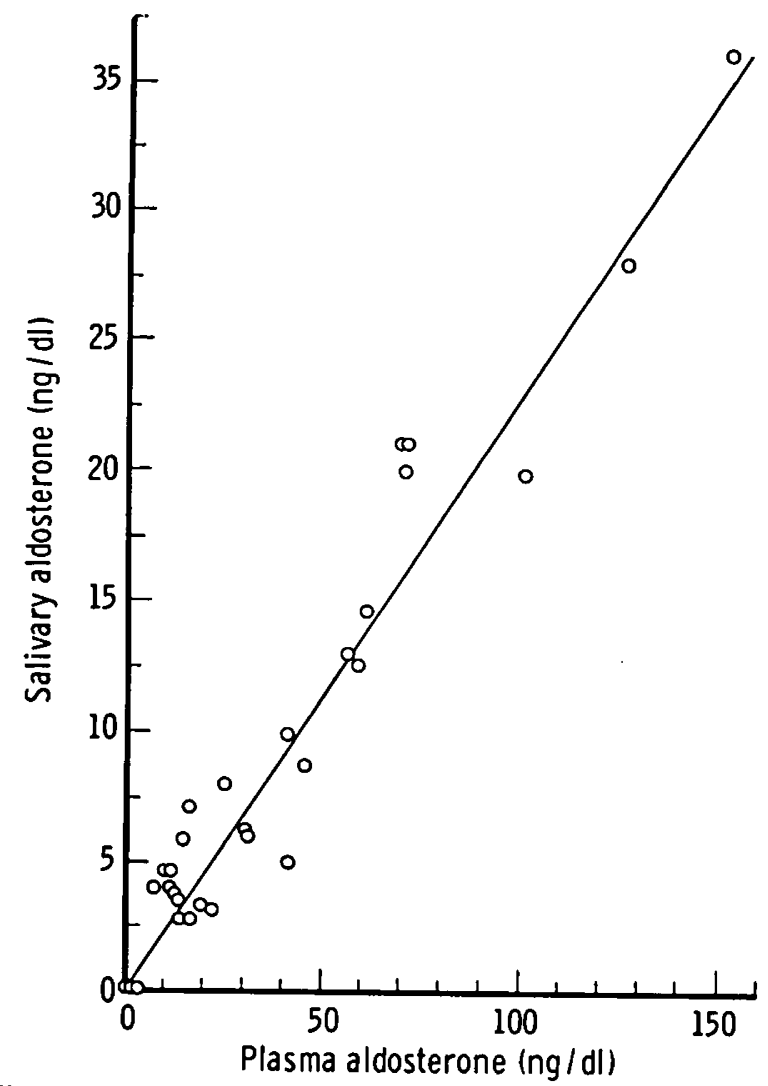

Fig. 1. Plasma aldosterone concentration vs. salivary aldosterone concentration. $(n=30, r=0.9644, P<0.001)$.

Table 3. Plasma and salivary hormones during base line state and during $A C T H$ administration ${ }^{1}$

\begin{tabular}{lcccc}
\hline & \multicolumn{4}{c}{ Concentration } \\
\cline { 2 - 5 } & $n$ & Plasma & $n$ & Salivary \\
\hline $\begin{array}{l}\text { Deoxycorticosterone } \\
\text { Baseline }\end{array}$ & 18 & $13.1 \pm 3.1$ & 39 & nondetectable \\
ACTH & 4 & $155 \pm 55$ & 4 & $6.37 \pm 2.4$ \\
$\begin{array}{l}\text { Corticosterone }(\mu \mathrm{g} / \mathrm{dl}) \\
\quad \text { Baseline }\end{array}$ & & & \\
ACTH & 10 & $0.43 \pm 0.25$ & 10 & $0.02 \pm 0.02$ \\
$\begin{array}{l}\text { Cortisol }(\mu \mathrm{g} / \mathrm{dl}) \\
\quad \text { Baseline }\end{array}$ & 10 & $13.7 \pm 5.7$ & 10 & $0.3 \pm 0.13$ \\
ACTH & 5 & $60 \pm 10$ & 5 & $5.8 \pm 2.3$ \\
\hline 'Results expressed
\end{tabular}

' Results expressed as mean \pm SD.

Corticosterone and cortisol were found in saliva at a level of 5$10 \%$ of the plasma level (Table 3 ).

\section{EFFECT OF FLOW ON SALIVARY ALDOSTERONE CONCENTRATION}

In three patients where salivary flow rate was changed while maintaining a constant plasma aldosterone concentration, the salivary aldosterone concentration was unaltered (Table 4). Thus, salivary aldosterone concentration reflected the plasma aldosterone concentration irrespective of salivary flow rate. The subjects sucked sour lemon drops to stimulate flow.

\section{SALIVARY ALDOSTERONE AS A MEASURE OF PLASMA FREE ALDOSTERONE}

The concentration of aldosterone which is protein bound, has been estimated to be between $30-90 \%(3-5,11,13,15-17)$. Previous investigators have noted consistent changes in aldosterone

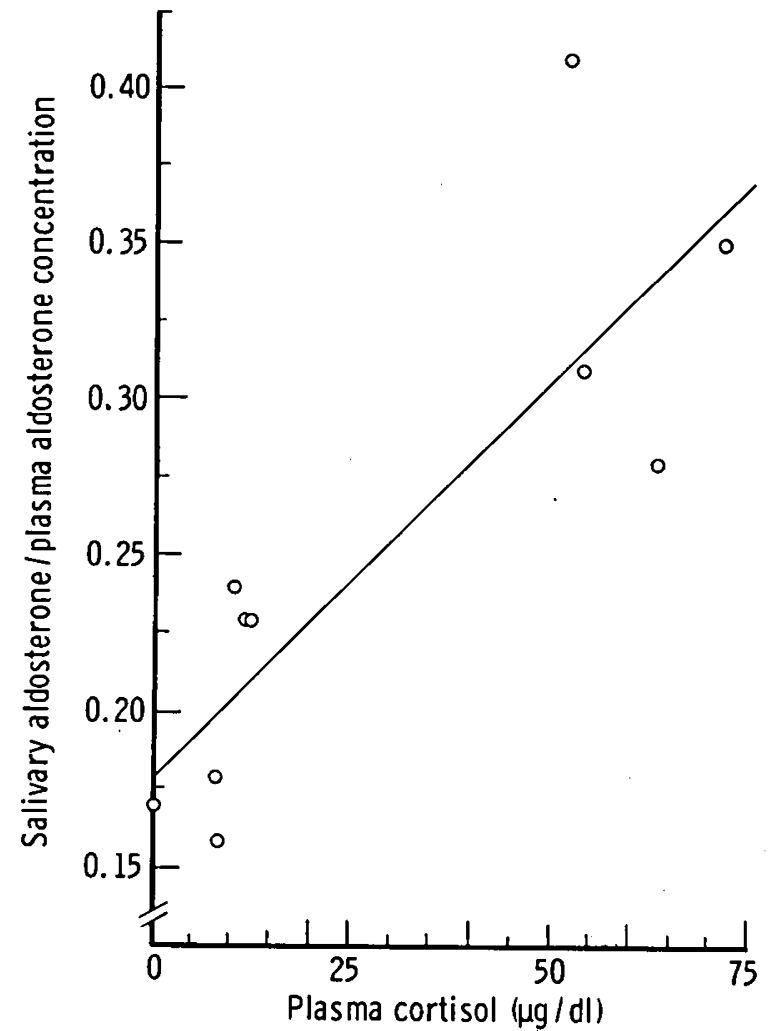

Fig. 2. Plasma cortisol vs. salivary aldosterone/plasma aldosterone concentration. $(n=10, r=0.8548, P<0.01)$.

Table 4. Salivary flow does not change salivary aldosterone concentration

\begin{tabular}{lccc}
\hline & $\begin{array}{c}\text { Flow rate } \\
(\mathrm{ml} / \mathrm{min})\end{array}$ & $\begin{array}{c}\text { Salivary aldoste- } \\
\text { rone concentration } \\
\text { (ng/dl) }\end{array}$ & $\begin{array}{c}\text { Plasma aldoste- } \\
\text { rone concentra- } \\
\text { tion (ng/dl) }\end{array}$ \\
\hline Patient 1 & 1 & 3.4 & 10.1 \\
& 4 & 2.9 & 10.1 \\
Patient 2 & 0.66 & 2.8 & \\
& 3.4 & 2.5 & 6.8 \\
Patient 3 & & & 6.8 \\
& 0.24 & 3.0 & 9.5 \\
& 4.0 & 2.5 & 9.5 \\
\hline
\end{tabular}

binding depending on the availability of corticosteroid binding globulin. When in vivo or in vitro experiments have been performed, protein bound aldosterone increased in states of increased corticosteroid-binding globulin (CBG) availability and decreased in states of decreased CBG availability (Table 5).

If salivary aldosterone represents plasma nonprotein bound aldosterone, the percent of protein bound aldosterone may be calculated by the formula:

$\%$ protein-bound aldosterone

$$
=100-\left(\frac{\text { salivary aldosterone concentration } \times 100}{\text { plasma aldosterone concentration }}\right)
$$

During dexamethasone administration, the protein bound aldosterone, as estimated by this formulation, increased, indicating increased available CBG; while, during ACTH stimulation, the protein bound aldosterone decreased, as would be expected, with low CBG. When we compared the protein-bound aldosterone in states of relatively increased availability of CBG (i.e., dexamethasone administration), or decreased CBG availability (i.e., ACTH administration), we noted that the calculated percent binding agreed with previously reported direct measurements of protein bound aldosterone for similar states of CBG availability (Table 
Table 5. Percent of aldosterone bound to protein reported by other investigators under various conditions ${ }^{1}$

\begin{tabular}{|c|c|c|c|}
\hline Investigator & $\begin{array}{l}\text { Percent bound high CBG } \\
\text { available }\end{array}$ & $\begin{array}{l}\text { Percent bound low CBG } \\
\text { available }\end{array}$ & Method of Analysis \\
\hline Chen et al. (3) & & $39-45$ & Ultrafiltration at $37^{\circ} \mathrm{C}$ \\
\hline Sandberg et al. (13) & 74 & 40 & Dialysis vs. saline (cortisol added in low CBG) \\
\hline Daughaday et al. (4) & 87.6 & 58.2 & $\begin{array}{l}\text { Dialysis (high CBG, dialysis at } 4^{\circ} \mathrm{C} \text {; low } \mathrm{CBG} \text {, dialysis } \\
\text { at } 37^{\circ} \mathrm{C} \text { with additional cortisol) }\end{array}$ \\
\hline Daughaday et al. (4) & 86.7 & 63 & $\begin{array}{l}\text { Ultrafiltration (high CBG, dialysis at } 4^{\circ} \mathrm{C} \text {; low CBG, } \\
\text { dialysis at } 37^{\circ} \mathrm{C} \text { ) }\end{array}$ \\
\hline Davidson et al. (5) & 73 & 30.9 & $\begin{array}{l}\text { Dialysis (high CBG, dexamethasone suppressed, low } \\
\text { CBG, ACTH stimulated) }\end{array}$ \\
\hline Meyer et al. (11) & 95 & 44 & $\begin{array}{l}\text { Dialysis (Enovid treated subjects; high } \mathrm{CBG} \text {, at } 4^{\circ} \mathrm{C} \text {; } \\
\text { low } \mathrm{CBG} \text {, at } 37^{\circ} \mathrm{C} \text { ) }\end{array}$ \\
\hline Siegenthaler et al. (15) & & $63-66$ & Ultrafiltration, at $37^{\circ} \mathrm{C}$ \\
\hline Varsano-Aharon and Ulick (16) & 90 & 49 & $\begin{array}{l}\text { Dialysis (low CBG, binding to } 5 \% \text { albumin), Ultrafil- } \\
\text { tration (high CBG, pure CBG) }\end{array}$ \\
\hline Zager et al. (17) & 69 & 38 & $\begin{array}{l}\text { Dialysis (high CBG, dexamethasone suppressed; low } \\
\text { CBG, cortisol added to dialysate) }\end{array}$ \\
\hline $\begin{array}{l}\text { This report } \\
\text { range } \\
\text { mean }\end{array}$ & $\begin{array}{l}78-84 \\
81\end{array}$ & $\begin{array}{c}55-74 \\
64\end{array}$ & $\begin{array}{l}\text { Saliva (high CBG, dexamethasone suppressed; low } \\
\text { CBG, ACTH stimulated) }\end{array}$ \\
\hline
\end{tabular}

' High CBG or low CBG refers to the relative amount of CBG available for binding aldosterone. The comment explains the method used to achieve relative low or high CBG.

\section{DISCUSSION}

Our studies have established that aldosterone can be measured in saliva. Changes in the salivary concentration of aldosterone resulting from alterations in plasma cortisol suggest that salivary aldosterone represents the nonprotein bound fraction of the circulating aldosterone. Presumably, changes in plasma cortisol can induce changes in the protein binding of aldosterone by competing with available CBG, as reported by several investigators $(13,17)$.

The work of Katz and Shannon (7-9), who demonstrated that the sum of cortisol and cortisone in saliva represented the free fraction in plasma, predicted that saliva aldosterone would also represent the unbound fraction. We have shown that the concentration of salivary aldosterone was biologically significant by demonstrating the relationship of the salivary aldosterone level to other significant physiologic parameters, including urinary aldosterone excretion, plasma aldosterone concentration, and plasma renin activity.

Further, we have demonstrated that salivary aldosterone reflects plasma aldosterone concentration under conditions of varying salivary flow rates.

Saliva is an accessible biological fluid which represents an ultrafiltrate of plasma. Because the unbound fraction is the biologically active fraction, measurement of salivary aldosterone assumes clinical importance. Salivary aldosterone measurements can be used to study aldosterone secretion and metabolism noninvasively. This has particular advantages in children in whom venipuncture and urine collection are cumbersome and and undesirable.

Katz and Shannon (8), using radiolabeled aldosterone, estradiol, and $\Delta 4$-androstenedione, were able to demonstrate the presence of the radioactivity in saliva after iv infusion. Because we have measured DOC and corticosterone in saliva, saliva may be used to investigate other steroids as well.

\section{REFERENCES AND NOTES}

1. Abraham, G. E., Buster, J. E., Lucas, L. A., Corrales, P. '̇., and Teller, R. C.: Chromatographic separation of steroid hormones for use of radioimmunoassay. Anal. Lett., 5: 509 (1972).

2. Charmakjian, Z. H., Pryor, W. W., and Abraham, G. E.: A radioimmunoassay for serum and urine aldosterone by celite column chromatography. Anal. Lett., 7: 97 (1974).

3. Chen, P. S., Mills, I. H., and Barter, F. C.: Protein binding of steroids. J. Endocrinol., 23: 129 (1961).

4. Daughaday, W. H., Holloszy, J., and Maviz, I. K.: Corticosteroid binding plasma protein. J. Clin. Endocrinol. Metab., 21: 53 (1965).

5. Davidson, E. T., DeVenuto, F., and Westphal, U.: Aldosterone-protein interaction. Endocrinology, 71: 893 (1962).

6. Haning, R., McCracken, J., St. Cyr, M., Underwood, R., Williams, G., and Abraham, G.: The evolution of titer and specificity of aldosterone binding antibodies in hyperimmunized sheep. Steroids, 20: 73 (1971).

7. Katz, F. H. and Shannon, 1. L.: Identification and significance of parotid fluid corticosteroids. Acta Endocrinol., 46: 393 (1964).

8. Katz, F. H. and Shannon, I. L.: Parotid fluid, cortisol and cortisone. J. Clin. Invest., 48: 848 (1969).

9. Katz, F. H. and Shannon, I. L.: Adrenal corticosteroids in submaxillary fluids. J. Dent. Res., 48: 448 (1969).

10. Manlimos, F. S., Maroulis, G. B., and Abraham, G. E.: Radioimmunoassay of plasma 11-deoxycorticosterone. Anal. Lett., 8: 931 (1975).

11. Meyer, C. J., Cayne, D. S., Tait, J. F., and Pincus, G.: Binding of aldosterone to plasma proteins. J. Clin. Invest., 40: 1663 (1961).

12. Roy, S. K., Garza, R., Maroulis, G., and Abraham, E.: Radioimmunoassay of plasma corticosterone. Anal. Lett., 7: 109 (1974).

13. Sandberg, A., Slaunwhite, W. R., and Carter, A. C.: Transcortin: a corticosteroid binding protein of plasma. J. Clin. Invest., 39: 1914 (1960).

14. Sealey, J. E., Laragh, J. H., Gerten-Banes, J., and Aceto, R. M.: The measurement of plasma renin activity in man. In: J. H. Laragh: Hypertension Manual, p. 621-640 (Dun-Donnelley Corp., New York, 1974).

15. Seigenthaler, W., Peterson, R. E., and Frimpter, G. W.: The renal clearance of aldosterone and its major metabolites. In: E. E. Baulieu and P. Robel: Aldosterone, A Symposium, p. 51 (Blackwell Scientific Publications, Oxford, 1964).

16. Varsano-Aharon, N. and Ulick, S.: Differences in antipodal specificity in the binding of steroids to serum proteins. J. Biol. Chem., 249: 4939 (1972).

17. Zager, P. G., Burtis, W. J., Luetscher, J. A., Dowdy, A. J., and Sood, S.: Increased plasma protein binding and lower metabolic clearance rate of aldosterone in plasma of low cortisol concentration. J. Clin. Endocrinol. Metab., 42: 207 (1976).

18. Zipser, R. D., Speckart, P. F., Zia, P. K., Edmiston, W. A., Lau, F. Y. K., and Horton, R.: The effect of ACTH and cortisol on aldosterone and cortisol clearance and distribution in plasma and whole blood. J. Clin. Endocrinol. Metab., 43: 1101 (1976).

19. This research was supported in part, by a grant from the USPHS, NIH (HD 00072, HL 17749); grant (RR 47) from the General Clinical Research Centers Program of the Division of Research Resources, USPHS, NIH; and by training grant (HL 05299) from the USPHS, NIH.

20. Requests for reprints should be addressed to: Maria 1. New, M.D., The New York Hospital-Cornell Medical Center, 525 East 68th Street, New York, New York, 10021, USA

21. Received for publication March 10, 1978.

22. Accepted for publication June $29,1978$. 